\title{
Vegetarian practices, body composition and dietary intake among Hindus and Buddhists in Kuching, Sarawak, Malaysia
}

\author{
Cheah Whye Lian' ${ }^{1}$, Chang Kam Hock ${ }^{2}$, Tang Mei Fong ${ }^{3}$, Lekkha Yuvaraj ${ }^{4}$, Ryan Dylan Aldrin ${ }^{5}$, \\ Noorhaswati Izura Ab Llah ${ }^{6}$
}

\begin{abstract}
${ }^{1}$ Associate Professor, Department of Community Medicine \& Public Health; ${ }^{2}$ Associate Professor, Medical Education Unit;
${ }^{3-6}$ Medical student; Faculty of Medicine and Health Sciences, Universiti Malaysia Sarawak, Kota Samarahan, Sarawak, Malaysia.
\end{abstract}

\section{Abstract}

Though vegetarians own the privilege of a wide range of health benefits and of much lower risk of many diseases, they are also cut off many essential nutritional values. This study aimed to determine the vegetarian practices, body composition and dietary intake of vegetarians among Hindus and Buddhists in Kuching, Sarawak. Using questionnaire and anthropometric measurement, this cross-sectional study was carried out in Hindu and Buddhist temples in Kuching. Data was entered and analysed using SPSS version 22. A total of 114 respondents participated in the study, with mean age of 45.8 years $(\mathrm{SD} \pm 16.01)$, females $(57 \%)$, and majority Buddhists $(81.6 \%)$. Majority of the respondents were on lacto-ovo vegetarian diet $(71 \%)$ with more among the Hindus. More than half of the respondents were overweight and obese $(64.1 \%)$. About $58 \%$ of the respondents were found to have abnormal waist circumference and $78.1 \%$ with over fat percentage. Buddhist respondents consumed more carbohydrates than Hindus. Hindu respondents consume more macro-nutrients such as protein and fat with a mean intake of $102.9 \mathrm{~g}(\mathrm{SD} \pm 34.60)$ and $20.9 \%$ of total energy intake respectively and more micro-nutrients. Vegetarian diet does not warranty healthy body as the quality and quantity of the food intake can influence the nutritional status of a person. Knowledge on choice of food should be imparted to improve their health status.

Keywords: Vegetarians, Hinduism, Buddhists, Nutritional status, Dietary intake.

\section{Introduction}

Over the past decade, vegetarian is becoming increasing popular in the present society. The increase in prevalence may be most likely due to benefits arising from various health-related factors (lower blood cholesterol levels and blood pressure, reduced risk of obesity and diabetes). ${ }^{1}$ Vegetarian diets are rich in fibres, complex carbohydrates but low fat content - therefore vegetarians are commonly found to have lower body mass indices than nonvegetarians, a much lower rate of death from ischemic heart disease due to the fact that vegetarians have been reported to show lower blood cholesterol levels, lower blood pressure, and lower rates of hypertension, type 2 diabetes. ${ }^{1,2}$ Legumes, fruits, vegetables, tomatoes allium vegetables, fibers and vitamin $\mathrm{C}$ which are also consumed considerably by vegetarians in higher amounts when compared to non-vegetarian., ${ }^{2,3}$ All these listed food and its nutrients contains anti-cancer agents which give one a much higher protection over cancer. ${ }^{2,3}$

Though vegetarians own the privilege of a wide range of health benefits and of much lower risk of many diseases, however they are also cut off many essential nutritional values. Their diet tends be lower in calories, saturated fat and cholesterol, protein levels, long-chain n-3 (omega-3) fatty acids, vitamin D, calcium, zinc, and vitamin B-12. ${ }^{4}$ Vegetarians in general, typically have a much lower concentration of vitamin B-12 in their blood. ${ }^{5}$ Based on a study conducted the mean serum vitamin B12 was highest among omnivores (281, 95\% CI: 270-292 pmol/1), intermediate among vegetarians (182, 95\% CI: $175-189 \mathrm{pmol} /$ 1) and lowest among vegans (122, 95\% CI: $117-127$

\section{Practice Points}

- Vegetarian diet is becoming increasing popular due to its benefits in improving health status and prevention of chronic diseases.

- There was a high proportion of the respondents were found to be overweight and obese, with abnormal waist circumference and over fat percentage.

- The calorie intake for both religion groups was above the recommended nutrient intake of Malaysia.

- Although there were differences in nutrient intake among the respondents, the differences were found to be minimal except for protein, fat and carbohydrate.

- This suggested that vegetarian diet like any normal non-vegetarian diet if not consume properly in quantity and quality could create health problem.

pmol/l). ${ }^{5}$ Reduced intake of vitamin B12 accounts for an increased in the prevalence of vitamin B12 deficiency. This may eventually lead to megaloblastic anemia, a variety of neuropsychiatric symptoms and elevated serum homocysteine levels. ${ }^{6}$ Vegetarian diets have also indicates a much lower concentration of

Correspondence: Dr Cheah Whye Lian, Associate Professor, Department of Community Medicine \& Public Health, Faculty of Medicine and Health Sciences, Universiti Malaysia Sarawak, 94300 Kota Samarahan, Sarawak, Malaysia. E-mail: wlcheah@unimas.my. 
calcium, vitamin D, vitamin B-12, protein, and $n-3$ ( $\omega$ 3 ) fatty acids, all of which of these elements provides an important role in maintaining bone health. ${ }^{7}$ Most of the time low bone mineral density (BMD) is associated with an increased risk of osteoporotic fracture especially in later stages of life, and diet is considered as an important modifiable risk factor linked to bone health of an individual. ${ }^{8}$ While vegetarian diets appear to exhibit a wide range health advantages, however there is conflicting evidence regarding the effect of these diets on long-term bone health. ${ }^{8}$

Compared to vegan, lacto-ovo vegetarians can easily meet their nutrient needs through the consumption of milk and milk/dairy products, and eggs, particular in protein, calcium, vitamin B intake. ${ }^{9}$

Systematic review using meta-analysis conducted by Dinu et al. ${ }^{10}$ covering 86 cross-sectional and 10 cohort studies reported there is a significant improvement in the nutritional status in vegetarians and vegan, compared to non-vegetarians. Although studies on nutritional status of vegetarians have been conducted extensively in other countries, the study of local vegetarian nutrition is sparse, particularly in Malaysia where vegetarianism is practiced among Hindus and Buddhists. In Kuching, Sarawak, vegetarian meals have gained its popularity among the Chinese and Indians whether by practice of religion or others, but there was no study carried out to determine the body composition of this population and their nutrients intake. In light of this, the study is aimed to identify the dietary habits and body composition among the vegetarian population in Kuching, Sarawak.

\section{Materials and methods}

This descriptive cross-sectional study was carried out among the respondents in the Buddhist and Hindu temples in Kuching, Sarawak as most of them were vegetarians. Kuching has a total population of 325,132 people, whereby only a minority of them practiced vegetarianism. The Chinese population is the second largest after the Malays. A number of Hindus constituting a small number of secularists also existed around the city in a report published by Department of Statistics, Malaysia. ${ }^{11}$ The selection of temples was based on the biggest and most patronized Buddhist and Hindu temples in Kuching. A total of two Buddhist temples and two Hindu temples were identified.

Prior request upon access to the temples and the permission to conduct this research were done through the chief priests of the temples. The temple devotees were informed about the aims and objectives of the research through the chief priest of the respective temples. All temple devotees were invited to participate in this study. Approximately, two visits were conducted for data collection in each temple. To increase the recruitment of respondents, the data collection was collected after respondents' prayers.

The inclusion criteria for the respondents for this study were vegetarians consuming vegetarian diet which was defined as those who abstains from the consumption of any form of meat and may include refraining from byproducts of animals such as dairy produced. The respondents must be vegetarians for more than 6 months and intend to continue on with it. They also must be 18 years old and above and intellectual capable at the time of data collection. Ethical approval was obtained from UNIMAS Medical and Ethics Committee. All respondents signed a written consent form to participate in the study

Using PS software 3.0.43, based on a prevalence rate with standard deviation of $3.1,{ }^{12}$ and the difference mean of $1.69,{ }^{12,13}$ study power of 0.8 and Type 1 error probability of 0.05 , a total of 119 sample (including attrition rate of $10 \%$ ) is needed for this study.

Data was collected using a self-administered questionnaire. The translated questionnaire in both English and Mandarin was adopted from Lee. ${ }^{14}$ It consists of respondents' socio-demographic information (age, race, gender, education level, occupation) in Part 1 , anthropometry measurement (weight, height, waist and hip circumference) and body composition measurements in Part 2, and dietary habit using food frequency questionnaire (FFQ) in part 3. Information gathered from Part 3 was based on 86 commonly consumed food items from 10 different categories of food with the standard portion size and five different frequency classification of consumption ranging from never to yearly. Food items were cereal and cereal product, legumes and legume products, egg, milk and milk products, fruits, vegetables, bread spread, beverages, and others which are frequency consumed by vegetarians. Operationalization of the FFQ was done by converting the consumption frequency values into $f$ requency of daily intakes for all items. Energy and macronutrient intakes, as well as sodium, calcium and iron intakes was calculated by multiplying the daily frequency of specific foods by a standard portion and by the amount of nutrient present in one gram. In order to get food amounts or daily nutrient intakes, the nutrient content of each food item need to be summed up.

Anthropometric measurements including height, weight were measured using a SECA body meter and SECA portable weighing scale respectively. Body Mass Index (BMI) was calculated and classified based on the World Health Organization (WHO)/International Association for the Study of Obesity (IASO)/International Obesity Task Force (IOTF) guidelines ${ }^{15}$, where a BMI of $23 \mathrm{~kg} /$ $\mathrm{m}^{2}$ and above was classified as overweight and a BMI of more than $25 \mathrm{~kg} / \mathrm{m}^{2}$ is classified as obese.

For the waist circumference, measurement was carried out using a non-elastic tape measure at the midpoint between the lower costal margin and the iliac crest. Abdominal obesity was defined as a waist measurement of $90 \mathrm{~cm}$ or greater for men and $80 \mathrm{~cm}$ or greater for women. ${ }^{16}$

Body fat percentage was measured with a TANITA SC-240MA portable body composition analyzer. Prior to measurement, the respondents were asked to remove their shoes and stockings and all metallic accessories to prevent inaccurate measurements. In addition, the machine was calibrated according to the respondents' gender, weight and age before the reading was taken. For body fat percentage, the 'underfat' and 'healthy' categories were combined into 'healthy' while the 'overfat' and 'obesity' categories were combined into 'overfat'. The classification of underfat, 
healthy and overfat was based on Gallagher et al. ${ }^{17}$

Data was entered and analyzed using SPSS Version 22.0. Descriptive and inferential statistical tests were carried out to answer the research objectives based on $p$ value of less than 0.05 (2-sided).

\section{Results}

A total of 114 vegetarians responded to this study. The female respondents constituted $57 \%$ of the sample with a mean age of 45.8 years ( $\mathrm{SD} \pm 16.01$ ). More than $85 \%$ of them were Chinese and majority of the respondents were Buddhist. The majority of the respondents $(72.8 \%)$ had been practicing vegetarianism for more than three years. Most of the respondents were lacto-ovo vegetarians, with majority were Buddhist $(81.6 \%)$. Table 1 shows the socio-demographic information and vegetarian practice of the respondents.

BMI, waist circumference \& fat percentage

The mean BMI of the total respondents are 24.7 \pm 4.54 $\mathrm{kg} / \mathrm{m}^{2}$. More than half of the respondents were found to be obese, and have abnormal waist circumference. The findings also indicated $78.1 \%$ of the respondents were over fat (Table 2).

Dietary intake of respondents

Table 3 shows the dietary intake of respondents. All the respondents meet an average energy intake in their diet at a mean of $2349.2 \pm 652.74 \mathrm{kcal}$. Among them, the Hindus have a higher mean intake of $2712.5 \pm 593.32 \mathrm{kcal}$ than that of the Buddhists. The Hindu group consumes more macro-nutrients with a mean protein intake of $136.0 \mathrm{~g} \pm 57.20$ and percentage of fat over total calorie of $20.9 \% \pm 7.04$ respectively. Yet, carbohydrate consumption is more in Buddhist group than that of Hindu group (total percentage of carbohydrate intake $67.7 \% \pm 8.65$ ). The study has shown that a higher proportion of Hindus consumed micro-nutrients such as calcium (mean intake 1697.13 $\mathrm{mg} \pm 780.87$ ), iron (mean intake 44.0mg \pm 21.39 ), retinol (mean intake $377.38 \mu \mathrm{g} \pm 250.67$ ), niacin (mean intake $19.9 \mathrm{mg} \pm 11.09$ ), vitamin $\mathrm{C}$ (mean intake $413.59 \mathrm{mg} \pm 501.85$ ), thiamine (mean intake $4.37 \mathrm{mg} \pm$

Table 1: Socio-demographic characteristics and vegetarian practice of respondents $(\mathrm{N}=114)$

\begin{tabular}{|c|c|c|c|}
\hline \multirow{2}{*}{ Variables } & \multicolumn{3}{|c|}{ Religion Group (mean \pm SD) $/$ n(\%) } \\
\hline & All & Buddhist (n=93) & Hindu $(n=21)$ \\
\hline Age (year) & $45.8 \pm 16.01$ & $47.7 \pm 16.01$ & $37.3 \pm 13.29$ \\
\hline \multicolumn{4}{|l|}{$\operatorname{Sex}$} \\
\hline Male & $49(43.0)$ & $39(41.9)$ & $10(47.6)$ \\
\hline Female & $65(57.0)$ & $54(58.1)$ & $11(52.4)$ \\
\hline \multicolumn{4}{|l|}{ Race } \\
\hline Chinese & $99(86.8)$ & $93(100.0)$ & $6(28.6)$ \\
\hline Indian & $15(13.2)$ & $0(0)$ & $15(71.4)$ \\
\hline \multicolumn{4}{|l|}{ Type of vegetarian } \\
\hline Semi & $2(1.8)$ & $2(2.2)$ & $0(0)$ \\
\hline Lacto-ovo & $81(71.1)$ & $75(80.6)$ & $6(28.6)$ \\
\hline Lacto & $18(15.8)$ & $7(7.5)$ & $11(52.4)$ \\
\hline Ovo & $4(3.5)$ & $4(4.3)$ & $0(0)$ \\
\hline Vegan & $9(7.9)$ & $5(5.4)$ & $4(19.0)$ \\
\hline \multicolumn{4}{|l|}{ Practising Vegetarianism (years) } \\
\hline$<$ half years & $1(0.9)$ & $0(0)$ & $1(4.8)$ \\
\hline Half to 3 years & $30(26.3)$ & $29(31.2)$ & $1(4.8)$ \\
\hline$>3$ years & $83(72.8)$ & $64(68.8)$ & $19(90.4)$ \\
\hline \multicolumn{4}{|c|}{ Reasons to Practice Vegetarian Diet * } \\
\hline Health & $80(70.2)$ & $73(91.3)$ & $7(8.8)$ \\
\hline Religion & $83(72.8)$ & $67(80.7)$ & $16(19.3)$ \\
\hline Moral & $55(48.2)$ & $44(80.0)$ & $11(20.0)$ \\
\hline Environmental & $45(39.5)$ & $41(91.1)$ & $4(8.9)$ \\
\hline Economic & $8(7.0)$ & $6(75.0)$ & $2(25.0)$ \\
\hline Family and Peer Influence & $32(28.1)$ & $26(81.3)$ & $6(18.7)$ \\
\hline
\end{tabular}

*multiple responses

Table 2: Health Profile of Respondents $(\mathrm{N}=114)$

\begin{tabular}{|c|c|c|c|c|}
\hline \multirow{2}{*}{ Variables } & \multicolumn{3}{|c|}{ Religion Group (mean \pm SD)/ n(\%) } & \multirow{2}{*}{$\boldsymbol{p}$-value } \\
\cline { 2 - 5 } & All & Buddhist (n=93) & Hindu (n=21) & 0.807 \\
\hline BMI $\left(\mathrm{kg} / \mathrm{m}^{2}\right)$ & $24.7 \pm 4.54$ & $24.7 \pm 4.55$ & $24.9 \pm 4.59$ & - \\
\hline Normal $\left(<23 \mathrm{~kg} / \mathrm{m}^{2}\right)$ & $41(36)$ & $33(35.5)$ & $8(38.1)$ & - \\
\hline${\text { Overweight }\left(23-25 \mathrm{~kg} / \mathrm{m}^{2}\right)}^{\text {Obese }\left(>25 \mathrm{~kg} / \mathrm{m}^{2}\right)}$ & $15(13.2)$ & $10(10.8)$ & $5(23.8)$ & - \\
\hline Waist Circumference & $58(50.9)$ & $50(53.8)$ & $8(38.1)$ & 0.552 \\
\hline Normal & $86.2 \pm 12.2$ & $86.54 \pm 12.16$ & $84.8 \pm 12.61$ & - \\
\hline Abnormal & $48(42.1)$ & $36(38.7)$ & $12(57.1)$ & - \\
\hline Fat percentage & $66(57.9)$ & $57(61.3)$ & $9(42.9)$ & 0.449 \\
\hline Healthy & $28.2 \pm 8.02$ & $27.95 \pm 8.09$ & $29.43 \pm 7.77$ & - \\
\hline Over fat & $25(21.9)$ & $22(23.7)$ & $3(14.3)$ & - \\
\hline
\end{tabular}

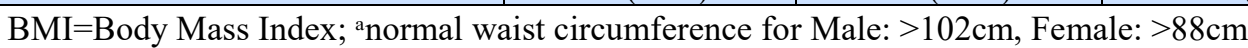

South East Asia Journal of Public Health 2018;8(1):3-9 
Table 3: Dietary Intake of Respondents $(\mathrm{N}=114)$

\begin{tabular}{|c|c|c|c|c|}
\hline \multirow[t]{2}{*}{ Variables } & \multicolumn{3}{|c|}{ Religion Group $(\operatorname{mean} \pm \mathrm{SD}) / \mathbf{n}(\%)$} & \multirow{2}{*}{$p$-value } \\
\hline & All & Buddhist $(n=93)$ & Hindu $(n=21)$ & \\
\hline Energy (kcal) & $2349.2 \pm 652.74$ & $2267.2 \pm 640.21$ & $2712.5 \pm 593.32$ & $<0.01$ \\
\hline Protein $(g)$ & $78.1 \pm 34.41$ & $72.5 \pm 31.58$ & $102.9 \pm 34.76$ & $<0.01$ \\
\hline Carbohydrate (\% of Energy) & $66.94 \pm 8.46$ & $67.7 \pm 8.65$ & $63.55 \pm 6.74$ & 0.041 \\
\hline Fat $(\%$ of Energy) & $18.3 \pm 7.59$ & $17.69 \pm 7.61$ & $20.9 \pm 7.04$ & 0.075 \\
\hline Calcium (mg) & $1101.2 \pm 943.12$ & $966.7 \pm 927.69$ & $1697.13 \pm 780.87$ & $<0.01$ \\
\hline Ferum (mg) & $30.4 \pm 19.11$ & $27.23 \pm 17.24$ & $44 \pm 21.39$ & $<0.01$ \\
\hline Retinol $(\mu \mathrm{g})$ & $291 \pm 246.45$ & $271.5 \pm 242.6$ & $377.38 \pm 250.67$ & $<0.01$ \\
\hline Niacin (mg) & $13.4 \pm 9.86$ & $11.9 \pm 8.99$ & $19.9 \pm 11.09$ & $<0.01$ \\
\hline Vitamin C (mg) & $246.8 \pm 260.47$ & $209.1 \pm 144.21$ & $413.59 \pm 501.85$ & $<0.01$ \\
\hline Thiamine (mg) & $2.8 \pm 2.1$ & $2.2 \pm 1.4$ & $4.37 \pm 2.14$ & $<0.01$ \\
\hline Riboflavin (mg) & $2.9 \pm 1.89$ & $2.62 \pm 1.69$ & $4.37 \pm 2.14$ & $<0.01$ \\
\hline Phosphorus(P) (mg) & $1525.3 \pm 959.50$ & $1326.8 \pm 828.79$ & $2404.3 \pm 1023.4$ & $<0.01$ \\
\hline Sodium(Na) (mg) & $1317.7 \pm 787.35$ & $1247.3 \pm 767.66$ & $1629.3 \pm 812.23$ & 0.044 \\
\hline Potassium(K) (mg) & $2576.1 \pm 1661.24$ & $2166.8 \pm 1168.67$ & $4388.76 \pm 2254.07$ & $<0.01$ \\
\hline
\end{tabular}

2.14), riboflavin (mean intake $4.37 \mathrm{mg} \pm 2.14$ ), phosphorus $(\mathrm{P})$ (mean intake $2404.3 \mathrm{mg} \pm 1023.40$ ), sodium $(\mathrm{Na})$ (mean intake $1629.3 \mathrm{mg} \pm 812.23$ ) and potassium (K) (mean intake $4388.76 \mathrm{mg} \pm 2254.07$ ).

\section{Food intake pattern}

Rice is taken daily by almost all subjects as it is the staple food of Malaysians (Table 4). Other carbohydrate foods consumed by more than $40 \%$ of the total respondents at least once a week include porridge, rice noodles and bread in which both groups of religion show the similar pattern. Overall, the consumption of mung bean, white soy bean and tau hoo is more than $50 \%$ at least once a week. However, the Hindus consumed lentils more than the Buddhist at least once a week. Chicken egg, salted duck egg and meat analogue are taken in a higher frequency. Grossly, Hindus consumed more milk and milk products. Above $60 \%$ of the total respondents prefers papaya, banana and apples at least once a week. Both Buddhists and Hindus consumed a wide variety of vegetables including cabbage, gourd, cucumber, mushroom and beansprout. These vegetables are consumed by a significant number of the respondents at least once a week. The Buddhists consumed coffee daily in a higher frequency while the Hindus consumed /drink coffee, soy bean drink and isotonic drink in a significant number at least once per week.

\section{Discussion}

This study aimed to determine the vegetarian practice, body composition and dietary intake among vegetarian practitioners from Buddhist and Hindu temples in Kuching, Sarawak. Based on the number of respondents, it is not surprising that more respondents from the Buddhist temples participated in this study as it fit into the profile of the demographic of Kuching where the Chinese population is the second most after the Malays, and only a minority of Hindus can be found. ${ }^{11}$ Nevertheless, there was a small percentage of the Hindus are Chinese $(6.11 \%)$.

In terms of number of years practicing, it is noted about three quarter of the respondents are on vegetarian diet more than three years, and with the highest percentage found among the Hindu respondents (90.5\%). Perhaps this is to do with the origin of the religion. Most Indian religions still strictly follow the philosophy that consumption of meat is forbidden, particularly from India the origin of Hinduism. ${ }^{18}$ Unlike Hinduism, not all Buddhists follow this philosophy of no meat. In certain part of countries such as Sri Lanka, Thailand, Cambodia, Burma and Laos, Buddhist monks and nuns are not allowed to grow, store or cook their own food; they mainly rely on the generosity of alms received and accept whatever food given including meat. ${ }^{19}$ In modern Buddhist world, attitudes towards vegetarianism vary by location and timing. Therefore, many of the Buddhists only practice semi-vegetarian diet. ${ }^{20}$

In this study, the main reason for practicing vegetarian diet was noted as religion $(72.8 \%)$. This finding is consistent with the fundamental teaching in both Hinduism and Buddhism where the principle of Ahimsa (nonviolence) and no killing of people or animals are practiced. ${ }^{21}$ However, among the Buddhist respondents, health was rated as the main reason $(91.3 \%)$ as compared to economic by the Hindu respondents (25\%). As reported by McEvoya et $a l .,{ }^{22}$ the most compelling reason of practicing vegetarian diet is of personal health where vegetarian diet can help to reduce risk of many chronic diseases because of its high content in fibers, complex carbohydrates, micronutrients and macronutrients.

Based on past epidemiologic studies, vegetarian diets are associated with a lower body mass index (BMI) and a much reduced prevalence of obesity in adults and children compared to non-vegetarian populations. ${ }^{23}$ However, this study showed otherwise. There were more than half of the respondents were overweight and obese $(64.1 \%)$, with the mean BMI of the respondents lied within the overweigh range for both groups (24.7 to $24.9 \mathrm{~kg} / \mathrm{m} 2)$. Similarly, for other health indicators where $57.9 \%$ were found to have abnormal waist circumference and $78.1 \%$ with over fat percentage.

According to the results, the overall energy intake for both groups was found to be high $2349.2 \mathrm{kcal}$ compared to the Malaysia Recommended Nutrient Intake $(\mathrm{RNI})^{24}$ where the recommended intake for male adults aged $30-50$ is $2460 \mathrm{kcal} /$ day and female adults aged $30-50$ is $2180 \mathrm{kcal} /$ day. At the individual religion group, the amount was found to 


\begin{tabular}{|c|c|c|c|c|c|c|c|c|c|c|c|c|c|c|c|c|c|c|c|c|c|c|c|c|c|c|c|c|c|}
\hline & 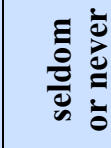 & & & $\mid \begin{array}{c}0 \\
0 \\
0 \\
d \\
0 \\
0\end{array}$ & 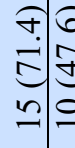 & $\left\{\begin{array}{l}0 \\
0 \\
0 \\
0 \\
0 \\
0\end{array}\right.$ & & & & & $\begin{array}{l}\infty \\
\dot{+} \\
- \\
-\end{array}$ & & & $\frac{a}{\tilde{j}}$ & & 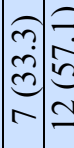 & $\begin{array}{l}0 \\
0 \\
0 \\
0 \\
0 \\
0\end{array}$ & & va & & 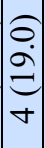 & & & 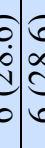 & $\vec{\nabla}$ & 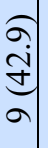 & $\tilde{a}$ & & \\
\hline त्ञ & 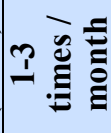 & & & $\mid$ & 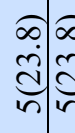 & 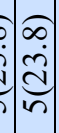 & $\begin{array}{l}\infty \\
\dot{d} \\
\\
i\end{array}$ & & $\underbrace{ \pm}_{ల}$ & $\frac{\pi}{2}$ & $\stackrel{\substack{\infty \\
+\\
-}}{-}$ & & $\begin{array}{l}\infty \\
\dot{\Xi} \\
\end{array}$ & 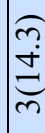 & & 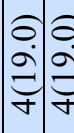 & 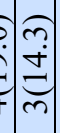 & & & $\overline{4} \frac{0}{r}$ & $\stackrel{m}{ \pm}$ & 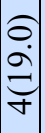 & $\overbrace{m}^{m}$ & & $\begin{array}{l}\tilde{d} \\
\stackrel{n}{n}\end{array}$ & & 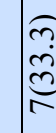 & & \\
\hline 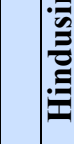 & 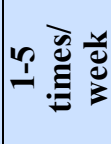 & & & 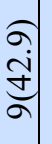 & 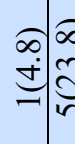 & 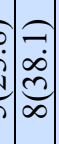 & & & $\simeq$ & 寄 & $\begin{array}{cc}R \\
\dot{n} \\
\infty \\
0 \\
0 \\
0 \\
0\end{array}$ & & 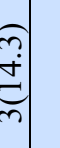 & ๙ি & & 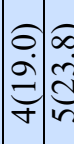 & 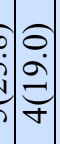 & & $\begin{array}{l}0 \\
8 \\
\end{array}$ & $=\begin{array}{l}0 \\
\dot{8} \\
\stackrel{+}{0}\end{array}$ & 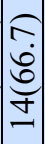 & 守 & 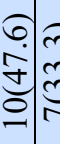 & & 守 & 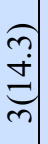 & 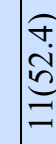 & & \\
\hline & 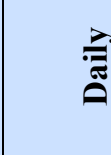 & & 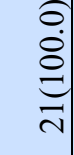 & & $\begin{array}{l}\infty \\
\pm \\
\end{array}$ & $\begin{array}{l}n \\
\vdots \\
\vdots \\
\vdots \\
\vdots \\
\vdots\end{array}$ & & & 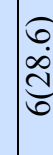 & ๙ึ & $\stackrel{\infty}{\infty}$ & & & $\stackrel{n}{2}$ & & $\begin{array}{c}6 \\
0 \\
\infty \\
\text { d్ర } \\
\end{array}$ & $\begin{array}{c}\overparen{1} \\
\infty \\
\infty \\
\infty \\
\infty\end{array}$ & 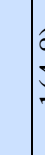 & 更 & & & 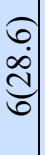 & 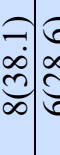 & $\begin{array}{c}0 . \\
\dot{0} \\
\dot{0} \\
0 \\
0\end{array}$ & 命 & 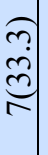 & $\stackrel{\infty}{ \pm}$ & 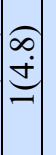 & \\
\hline & 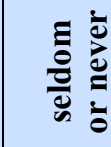 & & & 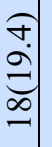 & 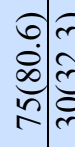 & 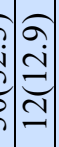 & है & & 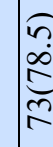 & - & $\mid \begin{array}{c}a \\
\vec{y} \\
\dot{y} \\
m\end{array}$ & & 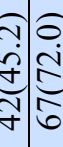 & $\stackrel{\infty}{\Xi}$ & & 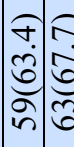 & 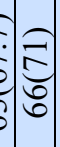 & & f. & $\stackrel{7}{\stackrel{7}{2}}$ & ? & $\begin{array}{l}\overrightarrow{0} \\
\stackrel{0}{n} \\
-\end{array}$ & & 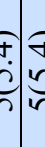 & $\stackrel{m}{+}$ & & ठิ & $\begin{array}{l}7 \\
0 \\
0 \\
0 \\
\infty \\
i\end{array}$ & \\
\hline 音 & 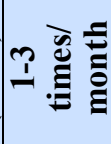 & & & 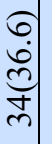 & 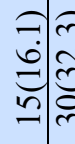 & 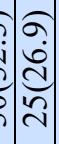 & |ר̃ & & $\stackrel{\infty}{\Xi}$ & त̂ & 告 & 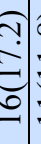 & 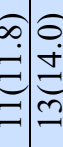 & 党 & & 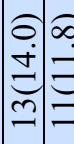 & t? & & ç & 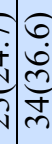 & 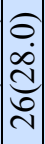 & 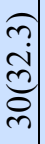 & 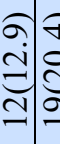 & ؛े & 弪 & 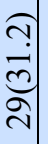 & 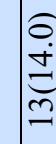 & ति & \\
\hline 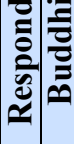 & 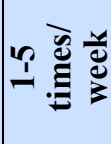 & & त़ & & สุ่ & 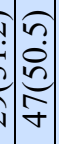 & 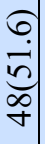 & & $\begin{array}{l}6 \\
\infty \\
\infty\end{array}$ & $\begin{array}{l}n \\
0 \\
g \\
0 \\
0\end{array}$ & \begin{tabular}{c}
$\hat{A}$ \\
\hdashline \\
$y$ \\
$y$ \\
$y$
\end{tabular} & 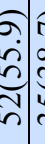 & 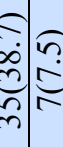 & 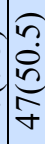 & & 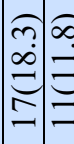 & 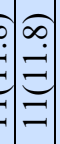 & & $\begin{array}{l}\infty \\
\dot{d} \\
b \\
n\end{array}$ & 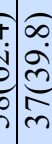 & $\begin{array}{l}7 \\
\infty \\
0 \\
0 \\
n \\
n\end{array}$ & 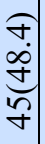 & 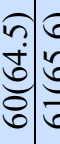 & 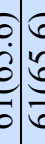 & 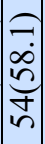 & 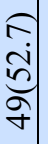 & $\begin{array}{l}6 \\
\text { ḋd } \\
\text { స̃ }\end{array}$ & 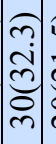 & \\
\hline & 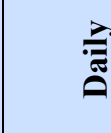 & & $\begin{array}{l}0 \\
\vdots \\
\vdots \\
\vdots\end{array}$ & $\begin{array}{l}\stackrel{f}{0} \\
\stackrel{n}{n}\end{array}$ & $\stackrel{\overbrace{}}{ت}$ & $\hat{\imath}$ & 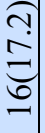 & & $\Xi$ & તู่ & 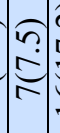 & है? & 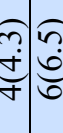 & $\frac{n}{\sqrt[n]{d}}$ & & 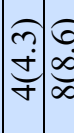 & & & & $=\begin{array}{c}0 \\
\infty \\
\infty \\
\infty\end{array}$ & $\stackrel{n}{2}$ & $\begin{array}{l}\tilde{n} \\
\tilde{n} \\
\tilde{m}\end{array}$ & 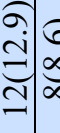 & $\begin{array}{cc}0 & 6 \\
\dot{0} & \alpha \\
& \alpha\end{array}$ & ¿্d & $\begin{array}{l}\sigma \\
\dot{\infty} \\
\infty\end{array}$ & 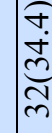 & 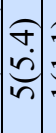 & \\
\hline & 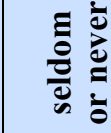 & & & 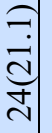 & 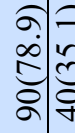 & 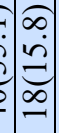 & \begin{tabular}{l}
$\infty$ \\
$\dot{\infty}$ \\
$\infty$ \\
\hdashline \\
-
\end{tabular} & & 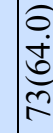 & $\stackrel{\overbrace{}}{\sim}$ & 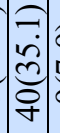 & $\sigma^{2}$ & 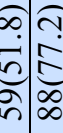 & $\stackrel{n}{\stackrel{n}{2}}$ & & 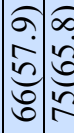 & 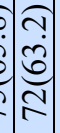 & & $\stackrel{2}{\dot{0}}$ & 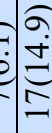 & \begin{tabular}{l}
$\infty$ \\
$\dot{\infty}$ \\
$\infty$ \\
\hdashline
\end{tabular} & 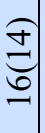 & 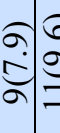 & 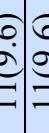 & O) & 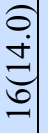 & 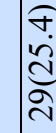 & 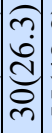 & \\
\hline & 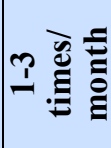 & & & 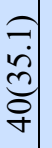 & 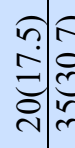 & 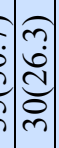 & 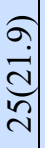 & & $\stackrel{\overbrace{}}{\stackrel{\overbrace{}}{J}}$ & 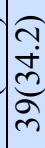 & (ొ) & : & 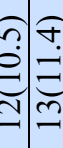 & 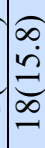 & & 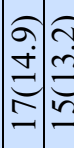 & 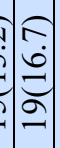 & & 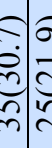 & $\underset{f}{\stackrel{\partial}{d}}$ & 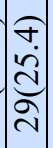 & $\mid$ & 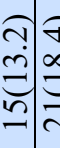 & 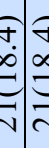 & 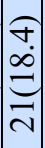 & 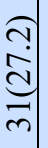 & ֶָ & 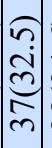 & \\
\hline & 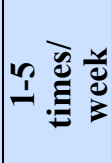 & & $\begin{array}{l}\sigma \\
\stackrel{d}{m} \\
m\end{array}$ & 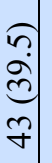 & 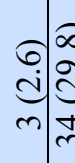 & $\begin{array}{c}\widehat{c} \\
\infty \\
0 \\
\vdots \\
n \\
n \\
0\end{array}$ & $\begin{array}{l}\overrightarrow{7} \\
\begin{array}{l}+ \\
0 \\
0 \\
n\end{array}\end{array}$ & & $\begin{array}{l}\tilde{n} \\
\text { I } \\
\text { ㄱ }\end{array}$ & 焉 & $\begin{array}{l}0 \\
i \\
i \\
8 \\
0\end{array}$ & $\begin{array}{l}n \\
\vdots \\
6 \\
6 \\
6\end{array}$ & 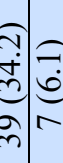 & $\frac{f}{\stackrel{f}{f}}$ & & 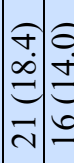 & 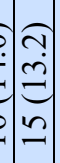 & & 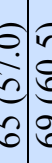 & 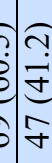 & $\mid \begin{array}{l}0 \\
0 \\
0 \\
\infty \\
0\end{array}$ & 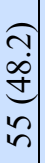 & 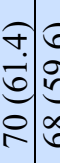 & $\begin{array}{ll}6 & 6 \\
0 \\
0 \\
0 \\
0 \\
0\end{array}$ & $\begin{array}{l}7 \\
0 \\
0 \\
0 \\
0 \\
0\end{array}$ & $\begin{array}{l}6 \\
\dot{y} \\
\dot{y} \\
i \\
i n\end{array}$ & $\begin{array}{l}\underset{\partial}{\infty} \\
\stackrel{\infty}{d} \\
\text { N }\end{array}$ & $\begin{array}{l}\hat{\sigma} \\
\dot{0} \\
0 \\
\vec{\gamma} \\
\vec{\gamma}\end{array}$ & \\
\hline & $\overline{\bar{\nu}}$ & & $\begin{array}{l}=\frac{n}{a} \\
= \\
\hat{\sigma}\end{array}$ & $\begin{array}{l}\stackrel{f}{+} \\
\stackrel{+}{ \pm}\end{array}$ & 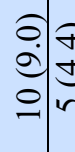 & $=\left[\begin{array}{l}6 \\
\vdots \\
= \\
=\end{array}\right.$ & 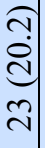 & & ๑. & 旅 & 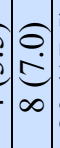 & 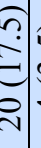 & 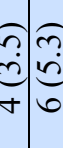 & $\stackrel{3}{3}$ & & $\begin{array}{ccc}\infty & \ddots \\
\infty & 0 \\
0 & 0 \\
0 & \infty & 0\end{array}$ & 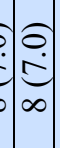 & & $\stackrel{\epsilon}{=}$ & $\dot{r} \vec{a}$ & $\underset{0}{-1}$ & $\begin{array}{l}\widehat{a} \\
\stackrel{5}{\sigma} \\
\sigma\end{array}$ & 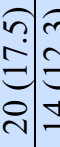 & ב̂ & $\mid \begin{array}{l}\vec{\sigma} \\
\infty \\
\vec{\sigma} \\
\vec{\sim}\end{array}$ & 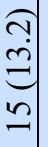 & $\begin{array}{l}\hat{\sigma} \\
\infty \\
\stackrel{d}{0} \\
m \\
m\end{array}$ & 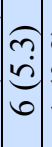 & \\
\hline & 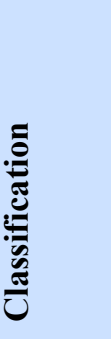 & 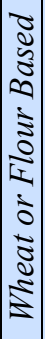 & $\begin{array}{r}.0 \\
\approx \\
\sim\end{array}$ & 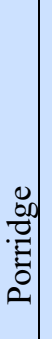 & 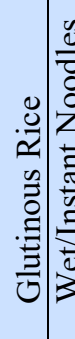 & 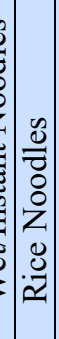 & 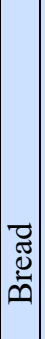 & 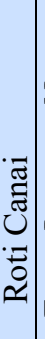 & $\bar{y}$ & 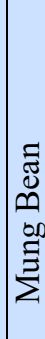 & 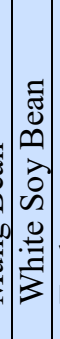 & : & 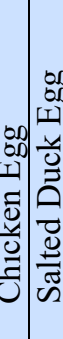 & 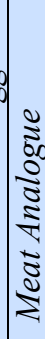 & 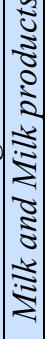 & 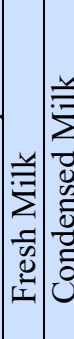 & 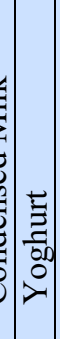 & . & 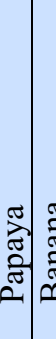 & 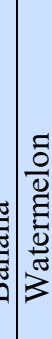 & $\frac{0}{2}$ & 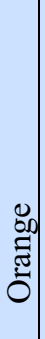 & 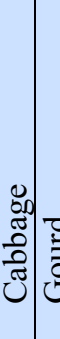 & ర్ & 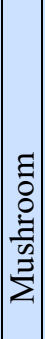 & 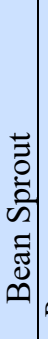 & 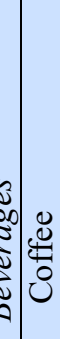 & 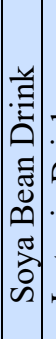 & \\
\hline
\end{tabular}


be from 2267.2 to $2712.5 \mathrm{kcal} /$ day. Such intake of calories was reflected in the high proportion of overweight and obese, abnormal waist circumference and body fat percentage among the respondents. This finding shows dissimilarity with other studies on vegetarians ${ }^{25}$ where a much reduced prevalence of obesity was found among adults and children who practicing vegetarian diet compared to non-vegetarian populations.

Macronutrient analysis reveals that energy density of the consumed diet by the Buddhist and Hindu respondents is contributed by different pattern of diet. The intake of carbohydrates, fats and proteins makes the difference between the Buddhist and the Hindu group; Buddhist respondents have a higher carbohydrate intake $(67.7 \%$ of total energy intake), slightly low fat intake $(17.69 \%$ of total energy intake) and a low protein intake (72.5g) compared to the Hindu respondents (carbohydrate intake $63.55 \%$ of total energy intake; fat intake $20.9 \%$ of total energy intake; protein intake $102.9 \mathrm{~g}$ ). Based on the results, it was found Buddhist respondents consumed more of porridge, glutinous rice, wet or instant noodles, rice noodles and bread while the Hindu respondents, even though they consume rice daily but the amount was lower. Although the Buddhist respondents frequently consume chicken eggs and duck eggs than the Hindu respondents, their consumption of fat was lower than the Hindu respondents. The protein intake of the Hindu respondents was higher, might be due to the higher intake of milk and milk products. However, the fat intake of the Buddhist respondents did not meet the recommended fat intake by Malaysia RNI 2005 (20 to $30 \%)^{24}$

The normal protein intake recommended by RNI for Malaysia is 55-62 g. ${ }^{24}$ The two groups in this study illustrate a disproportionate intake of protein plus higher than the recommended value. This shows that protein might be the main contributor to the total energy intake for both groups as supported by Lee \& $\mathrm{Krawinkel}^{25}$ and Davey et $a l .^{26}$ They have reached the RNI protein recommendation for Malaysia. When comparing both the groups, the Hindu respondents consumed a greater percentage of proteins than the Buddhist group. The main sources of proteins are lentils, mung bean, white soya bean and tauhoo. Increased consumption of milk and milk products helps to contribute to the high protein intake.

Milk and milk products are the leading source of calcium for both Buddhist and Hindus. Achieving adequate amount of calcium intake without supplements depends on the consumption of dairy products. According to the literatures, vegetarians consume much lower amount of calcium and vitamin D because of low intake of calcium- containing foods and vegetables with poor calcium bioavailability. 7,27 The findings of this study shows otherwise with both Hindu and Buddhist respondents reported to have reached the recommended intake of $800 \mathrm{mg}$ to $1000 \mathrm{mg}$. ${ }^{24}$ In contrast to the literature, the Hindu respondents consumed greater amount of calcium than the Buddhist respondents, exceeded the recommended range of calcium intake.

The iron intake for the both groups in this study was fairly high and exceeded the recommended value (10-15 $\mathrm{mg}$ /day based on Malaysia RNI 2005). This is also supported by the studies done before by Lee \&
Krawinkel $^{25}$, Davey et $a{ }^{26}$, Shridhar et al. ${ }^{28}$ Hindu respondents reported with a greater intake of iron than the Buddhist group. This may be due to their increased consumption of non-heme iron which is found in plant sources like legumes, lentils and their bio-availability is increased with concomitant intake of vitamin-C rich diet like orange as supported by Shridhar et al. ${ }^{28}$

High intake of thiamine, riboflavin and phosphorus among the vegetarians in this study was consistent with the RNI for Malaysia 2005. ${ }^{24}$ On the other hand, retinol varied far from the recommended value. This might be due to overconsumption of the respondents. Both Buddhist and Hindu respondents had shown a very high intake of vitamin $\mathrm{C}$. The value has gone far from the recommended value which was supposed to be $70 \mathrm{mg}$ for male and female. However, this result was consistent with the results of previous studies indicating ovo-lacto vegetarians consume higher retinol content in their food. Fruits and green leafy vegetables are the main sources of vitamin $\mathrm{C}$ and retinol. This shows vegetarians may have a better antioxidant profile which can be a better prevention approach towards chronic diseases such as coronary artery disease, chronic obstructive pulmonary disease and cancer. ${ }^{2,3,22}$ The Buddhist respondents had reported to have a lower consumption of niacin compared to the Hindu respondents. They did not reach the recommended value which was $14 \mathrm{mg}$ for female and $16 \mathrm{mg}$ for male based on RNI for Malaysia $2005 .^{24}$ This may be due to the low bioavailability of niacin in foods they consumed. Thus, strict vegetarians are advised to take supplementation of B complex as food plants do not contain niacin.

Like any survey research, the issue of response bias in this study is unavoidable. As this study was carried out among the vegetarians in Buddhist and Hindu temples, therefore there is limitation in generalization the findings. Nevertheless, the findings provide some baseline information with regards to the vegetarian practices in Kuching.

\section{Conclusion}

In conclusion, there was a high proportion of the respondents were found to be overweight and obese, with abnormal waist circumference and over fat percentage. This suggested that vegetarian diet like any normal non-vegetarian diet if not consume properly in quantity and quality could create health problem. In this study population, the calorie intake for both religion groups was above the recommended nutrient intake of Malaysia. Although there were differences in nutrient intake among the respondents, the differences were found to be minimal except for protein, fat and carbohydrate.

Although potentially lower in some nutrients, vegetarian diet if plan carefully can help to ensure the nutrient intake of vegetarian meet the recommended intake of all essential nutrient. A healthy well-planned vegetarian diet provides many health benefits that prevents many chronic diseases and is showed to increase longevity among the vegetarians. A vegetarian diet may present a significant advantage over meat-based diets, overweight and obesity issue is a complex issue caused by a variety of factors. Promotion of healthy lifestyle through imparts of knowledge on healthy diet, increase of physical activity, decrease of sedentary lifestyle and 
stress would be a more holistic approach. Since these respondents were under the religious institution, health talk would be an ideal approach in creating awareness on the important of proper meal planning.

\section{Competing interest}

The authors declared that there is no conflict of interest. This study received no specific grant from any funding agency in the public, commercial or not-for-profit sectors.

\section{Acknowledgement}

The authors would like thank the support from all participating religious leaders.

\section{References}

1. Craig WJ. Health effects of vegan diets. $A m J$ Clin Nutr 2009;89(suppl):S1627-33.

2. Siani V, Mohamed EI, Maiolo C, Di Daniele N, Ratiu A, Leonardi A,De Lorenzo A. A Body composition analysis for healthy Italian vegetarians. Acta Diabetol 2003;40(S1):S297-8.

3. Leitzmann C. Nutrition ecology: the contribution of vegetarian diets. Am J Clin Nutr 2003;78 (suppl):657S-9S.

4. Larsson CL, Johansson GK. Dietary Intake and Nutritional Status of Young Vegans and Omnivores In Sweden. Am J Clin Nutr 2002;76 (1):100-6.

5. Gilsing AM, Crowe FL, Lloyd-Wright Z, Sanders TAB, Appleby PN, Allen NE, Key TJ. Serum concentrations of vitamin $\mathrm{B} 12$ and folate in British male omnivores, vegetarians and vegans: results from a cross-sectional analysis of the EPIC-Oxford cohort study. Eur J Clin Nutr 2010;64 (1): 933-9.

6. Langan RC, Zawistoski KJ. Update on vitamin B12 deficiency. Am Fam Physician 2011;83 (12):1425-30.

7. Tucker KL. Vegetarian diets and bone status. Am J Clin Nutr 2014;100(Suppl):311S-12S.

8. Knurick J, Johnston C, Wherry S. Association between vegetarian diets and bone health. FASEB J 2014;28(1):823.2.

9. Clarys P, Deliens T, Huybrechts I, Deriemaeker P, Vanelst B, De Keyzer W, et al. Comparison of nutritional quality of the vegan, vegetarians, semi vegetarian, pesco-vegetarian and omnivorous diet. Nutrients 2014;6:1318-32.

10. Dinu M, Abbate R, Gensini GF, Casini A, Sofi F. Vegetarian, vega diets and multiple health outcomes: a systematic review with metaanalysis of observational studies. Crit Rev Food Sci Nutr 2017;57(17):3640-9.

11. Department of Statistics Malaysia. Sarawak. 2010. https://www.statistics.gov.my (accessed May 2018)

12. Wong YS, Shalini S, Farah Liana MR, Nurul Amera WMS. Nutrient Intake Pattern of Vegetarians and Non-vegetarians in Kuala Lumpur, Malaysia. PJN 2013;12(4):371-6.
13. Khor GL, Voon PC, Tee ES, Hsu-Hage BH, Wahlqvisr ML. Cardiovascular Risk Factors among Malaysian Urban Vegetarians. J Community Nutr 2000;2(2):110-8.

14. Lee KW. Tabiat makanan di kalangan vegetaran etnik Cina di Kota Kinabalu dan Ipoh (In Malay): Food habits among ethnic Chinese vegetarians in Kota Kinabalu and Ipoh. Thesis. B. Food Sc. (Hons.). Universiti Malaysia Sabah, 2011.

15. World Health Organisation, International Association for the Study of Obesity, International Obesity Task Force, The Asia-Pacific perspective: Redefining obesity and its treatment. Sydney: Health Communications, 2000.

16. International Diabetes Federation (IDF). The IDF consensus worldwide definition of the Metabolic Syndrome, IDF, Belgium, 2006.

17. Gallagher D, Visser M, Sepulveda D, Pierson RN, Harris T, Heymsfield SB. How useful is body mass index for comparison of body fatness across age, sex, and ethnic groups? Am J Epidemiol 1996;143(3):228-39.

18. Rosen S. Food for the spirit, vegetarianism and the world religions. New York, Bala Books Inc. 1990.

19. Oldenberg H. Book of Discipline No.4. Vinayapitaka Vol.4. Suttavibhanga Pt.2. Sri Lanka, Pali Text Society. 1938.

20. Kieschnick J. Buddhist vegetarianism in China In:Sterckx R. (eds) of Tripod and Palate. New York, Palgrave Macmillan. 2005.

21. Van Horn G. Hindu Traditions and Nature: Survey Article. Worldviews Global Religions Culture Ecology 2006;10(1):5-39.

22. McEvoya CT, Temple N, Woodsidea JV. Vegetarian diets, low-meat diets and health: a review. Public Health Nutr 2012;15(12):2287-94.

23. Sabate J, Wien M. Vegetarian diets and childhood obesity prevention. Am J Clin Nutr 2010;9:1525s-9s.

24. Ministry of Health Malaysia. A Report of the Technical Working Group on Nutritional Guidelines. 2005.

25. Lee Y, Krawinkel M. Body composition and nutrient intake of Buddhist vegetarians. A sia Pac J Clin Nutr 2009;18(2):265-71.

26. Davey GK, Spencer EA, Appleby PN, Allen NE, Knox KH, Key TJ. EPIC-Oxford: lifestyle characteristics and nutrient intakes in a cohort of 33883 meat-eaters and 31546 non-meat-eaters in the UK. Public Health Nutr 2003;6(3): 25969.

27. Tesar R, Novotelovitz M, Shim E, Kauwell G, Brown J. Axial and peripheral bone density and nutrient intakes of postmenopausal vegetarian and omnivorous women. Am J Clin Nutr 1992;56:699-704.

28. Shridhar K, Dhillon PK, Bowen L, Kinra S, Bharathi AV, Prabhakaran D, Reddy KS, Ebrahim S. Nutritional profile of Indian vegetarian diets - the Indian Migration Study (IMS). Nutr J 2014;13(55):1-9. 